\title{
Changes in the physicochemical characteristics of low-salt Doenjang by addition of halophytes
}

\author{
Bo-Young Choi, Na-Young Gil, Ji-Young Mun, Soo-Hwan Yeo, So-Young Kim* \\ Fermented and Processed Food Science Division, National Institute of Agricultural Science, RDA, Wanju 55365, Korea
}

\section{염생식물 첨가 저염된장의 이화학적 특성 변화}

\author{
최보영 · 길나영 · 문지영 · 여수환 · 김소영* \\ 농촌진흥청 국립농업과학원 발효가공식품과
}

\begin{abstract}
The aim of this study was to investigate changes in the physicochemical characteristics of Doenjang fermented with halophyte powder for 24 weeks. The $\mathbf{p H}$ of all Doenjang samples slightly decreased during the fermentation period, with a range of 5.3-6.1. The acidity peaked at 8 weeks and subsequently decreased. The content of amino-type nitrogen steadily increased during fermentation and peaked at $1,174.6 \pm 18.2 \mathrm{mg} \%$ in Doenjang without halophyte powder. On the other hand, in the same sample, the reducing sugar content decreased to $1.0 \pm 0.0 \mathrm{mg} \%$. Total bacterial counts slightly decreased during fermentation, but there was no significant difference according to the addition of halophyte powder. In the analysis of taste components using a taste sensor, the richness value was higher in the halophyte Doenjang (4.01 to 7.52) compared with that in the commercial Doenjang, and the sourness (-3.65 to -1.33$)$ and bitterness $(-1.63$ to -0.27$)$ were lower than those of the commercial Doenjang. Several characteristics were different depending on whether halophyte powder was added, but halophyte powder did not appear to affect the microbial growth. Thus, Doenjang can be produced with superior properties and taste components and improved functionality and taste using halophytes.
\end{abstract}

Key words : Doenjang, halophytes, low-salt

\section{서 론}

된장은 우리나라 고유의 전통발효식품으로, 된장 제조 시 주원료가 되는 콩은 곡류 단백질에서 부족하기 쉬운 필수아미노산, 지방산, 유기산, 비타민 등의 영양을 보충해 주는 역할을 하여 영양학적 측면에서 가치가 높다(1). 또한 된장이 발효되면서 생성되는 대사산물로 인한 항돌연변이 및 항암(2), 항산화작용(3), 면역증강 효과(4), 콜레스테롤 저하 효과(5) 등 다양한 기능성 연구가 활발히 이루어지고 있다. 그러나 된장 제조 시에 사용되는 소금이 미생물 생장

*Corresponding author. E-mail : foodksy@korea.kr Phone : 82-63-238-3610, Fax : 82-63-238-3843

Received 2 October 2018; Revised 8 November 2018; Accepted 11 November 2018.

Copyright (c) The Korean Society of Food Preservation. All rights reserved.
조절과 저장성 향상을 위해서 필수 재료이긴 하지만 시판 된장이 평균적으로 약 10-14\% 농도를 나타내고, 특히 한식 된장의 경우에는 염 농도가 $20 \%$ 까지 높아 영양기능적 측면 에서 우수한 된장이 나트륨 과잉 섭취의 원인으로 인식되어 장류 소비시장에까지 영향을 주고 있다(6). 이에 최근에는 장류 소비 확대 및 소비자 관심증대를 위해 맛과 기능성이 향상된 된장을 개발하기 위하여 녹차(7), 다시마(8), 고구마 (9), 버섯(10), 발효옻(11) 그리고 마늘(12) 등 다양한 재료를 첨가하는 시도를 많은 연구자들이 하고 있다.

염생식물은 해조류와 같이 염분이 많은 해안 주변의 염 생습지에서 서식하며 먹이연쇄의 기초 생산자로서 역할을 하는 식물이다. 최근 다양한 약리 효과와 오염물질의 정화 능력으로 인해 관심의 대상이 되었으며 재배를 통한 이용 가능성도 날로 증가하고 있다(13-15). 뿐만 아니라 아직 검 증하지 못한 해양생물자원이 가진 기능성 성분의 발굴 및 효능에 대한 다양한 연구가 진행되고 있다(16-18). 특히 육 
상식물과는 달리 염 스트레스로부터 자신을 보호하기 위해 서 다양한 자기 방어 기작이 있으며 페놀성 화합물을 포함 하여 2차 대사산물을 다량 함유하고 있다고 보고된 바 있다 (19). 지구상에 알려진 염생식물은 약 1,600 여종이고, 우리 나라에 자생하고 있는 염생식물은 약 40여종이 알려져 있 다(20). 이들 중 퉁퉁마디라고도 불리는 함초(Salicornia europaea)는 명아주과(Chenopodiaceae)에 속하는 1년생 식 물로 칠면초, 나문재와 함께 우리나라에서 자생하는 대표 적인 염생식물로서 변비개선, 체중 조절, 항당뇨, 콜레스테 롤 저하, 항산화, 그리고 면역증강 작용 등 생리활성이 과학 적으로 입증되어 있어 기능성식품 소재로 다양하게 활용되 고 있다(21). 또한 함초와 같이 명아주과에 속하는 칠면초 (Suaeda japonica)의 경우도 추출물의 항산화 활성(22), B16BL6 mouse melanoma cell에서 tyrosinase 활성 및 melanin 생성 억제로 인한 미백 활성을 갖는다고 보고된 바 있다(23). 나문재(Suaeda asparagoides 또는 Suaeda glauca)는 단순 성분 분석을 통한 영양적 가치와 효능을 알아보는 연구가 진행되어 있을 뿐, 아직까지 기능성에 관 한 연구가 그다지 많이 이루어지지 않았다(24). 그러나 무엇 보다 염생식물은 약 $20 \%$ 정도로 높은 염을 함유하고 있어 요리의 재료나 소스, 소금 대체재로 보편적으로 사용가능 하여 조미료 개발에 있어 부재료로서 활용 가치가 있다(25).

본 연구에서는 나트륨 과잉 섭취의 원인으로 지적되고 있는 된장 내 소금을 염생식물(함초, 칠면초, 나문재) 분말 로 대체하여 저염된장을 제조하고 염생식물 분말의 종류와 첨가 비율에 따라 된장의 발효기간 동안 이화학적 특성 변화를 조사하였다.

\section{재료 및 방법}

\section{재 료}

본 실험에 사용된 대두는 대원콩 품종으로 2016년 5월 안동에서 생산된 것을 구입하였으며, 염생식물(함초, 칠면 초 및 나문재) 분말은 2016년 신안에서 재배, 건조하여 분말 화한 것을 (주미가식품에서 구입하였고, 소금은 간수를 뺀 천일염 $(\mathrm{CJ})$ 을 구입하여 사용하였다.

\section{콩알메주 제조}

콩알메주의 제조는 Park 등(26)의 방법을 참고하여 제조 하였으며, 종균으로 황국인 Aspergillus oryzae(KACC 46471)를 한국농업미생물자원센터에서 분양받아 사용하 였다. 배양용 배지로 Potato Dextrose Agar(PDA, Difco, $\mathrm{USA})$ 에 도말하여 $30^{\circ} \mathrm{C}$ 에서 48 시간 배양 후 포자를 수거하 여 포자수를 $1 \times 10^{7}$ 으로 일정하게 희석하였다. 일정량의 콩 을 15 시간 수침하여 불린 후, 1 시간 절수하고 고압 멸균기 (Autoclave, Vision Scientific Co., Daejeon, Korea)에 $121^{\circ} \mathrm{C}$
에서 60분간 삶았다. 삶아진 콩의 무게를 잰 후 Aspergillus oryzae(KACC 46471)를 총량의 $2 \%$ 접종하여 항온항습기 (Ilsin Lab Co., Ltd., Yangju, Korea)에 온도 $30^{\circ} \mathrm{C}$, 습도 $80 \%$ 에서 24시간 배양하였다. 하얗게 균사체가 발견되면 배양 을 종료하였다.

\section{염생식물 된장의 제조}

완성된 콩알메주를 믹서기(HMF-3500TG, Hanil, Seoul, Korea)를 이용해서 거칠게 갈고 Table 1에 따라 물, 소금, 염생식물 분말(함초-Salicornia europaea, 칠면초-Suaeda japonica, 나문재-Suaeda asparagoides)을 배합하여 된장을 제조하였다. 제조된 된장은 밀폐용기 $(3.5 \mathrm{~L})$ 에 담아 $30^{\circ} \mathrm{C}$ 에 서 0-6개월간 발효시키면서 4주 간격으로 시료를 채취하여 분석에 사용하였다.

Table 1. The composition of Doenjang manufactured according to the concentration of salt and halophyte powder (fix the amount of grain-type $\mathrm{Meju}$ )

\begin{tabular}{cccccc}
\hline Salt Conc. & Sample $^{1)}$ & Powder (g) Grain-type $M e j u$ (g) & Salt (g) & Water (g) \\
\hline \multirow{2}{*}{$8 \%$} & Control & 0 & 1,800 & 160 & 40 \\
& 5SE, SJ, SA & 110 & 1,800 & 154 & 140 \\
& 10SE, SJ, SA & 240 & 1,800 & 144 & 260 \\
\hline
\end{tabular}

${ }^{1)}$ SE, Salicornia europaea, SJ, Suaeda japonica; SA, Sulaeda asparagoides.

\section{수 분}

수분 함량 측정을 위해 $\mathrm{AOAC}$ 법(27)에 따라 $105^{\circ} \mathrm{C}$ 상압 건조법에 의해 분석하였으며, 된장 $1 \mathrm{~g}$ 을 $105^{\circ} \mathrm{C}$ Dry oven(MOV-112, Sanyo Co., Ltd., Osaka, Japan)에서 항량이 될 때까지 건조시켜 백분율(\%)로 계산하였다.

\section{염 도}

염도는 $\mathrm{AgNO}_{3}$ 적정법(28)을 변형하여 측정하였다. 된장 $5 \mathrm{~g}$ 에 증류수로 20배 희석하여 진탕배양기(SI-IS20 model, Shin-il Co., Seoul, Korea)에서 $160 \mathrm{rpm}$ 으로 1시간 동안 추출 후 여과지(Advantec No.2)로 여과하고 여액 $10 \mathrm{~mL}$ 에 지시 약 $\left(5 \% \mathrm{~K}_{2} \mathrm{CrO}_{4}\right)$ 을 첨가하여 $0.1 \mathrm{~N} \mathrm{AgNO}_{3}$ 로 적정하였다.

$\mathrm{pH}$

된장 시료를 일정량 취하여 증류수로 5 배 희석하고 homogenizer(Polytron PT-MR 2100, Kinematica AG, Lucerne, Switzerland)로 균질화한 후 $8,000 \mathrm{rpm}$ 에서 10 분간 원심분리(Supra 25k, Hanil Co., Ltd., Incheon, Korea)한 상층 액을 여과지(Advantec No.2)로 여과하여 시료액으로 사용 하였다. 이 시료액을 $\mathrm{pH}$ meter(Corning 340 , Corning Co., Corning, NY, USA)로 분석하였다. 
산 도

산도는 $\mathrm{pH}$ 측정에 사용한 동일한 시료액 $10 \mathrm{~mL}$ 에 $1 \%$ phenolphthalein 지시약을 첨가하여 시료의 $\mathrm{pH}$ 가 8.3이 될 때까지 소비된 $0.1 \mathrm{~N} \mathrm{NaOH}$ 의 양을 측정하였다.

\section{환원당}

환원당 함량은 DNS법(29)에 따라 분석하여 측정하였다. 시료액 $1 \mathrm{~mL}$ 에 DNS 시약 $3 \mathrm{~mL}$ 을 혼합하여 $100^{\circ} \mathrm{C}$ 의 물에서 5 분 동안 중탕한 것을 충분히 식힌 후 spectrophotometer (Libra S35, Biochrom Ltd., Cambridge, England)를 이용하여 $550 \mathrm{~nm}$ 에서 흡광도를 측정하였다. 포도당을 표준물질로 하여 작성한 검량곡선으로부터 환원당 함량(\%)을 계산하 였다.

\section{색 도}

색도는 색도계(Minolta CR-300, KONICA MINOLTA, Osaka, Japan)를 이용하여 측정한 후 Hunter $\mathrm{L}, \mathrm{a}, \mathrm{b}$ 값과 $\triangle \mathrm{E}$ 값으로 나타내었다.

\section{아미노태 질소}

아미노태 질소( $\left.\mathrm{NO}_{3}-\mathrm{N}\right)$ 는 Formol법(27)을 토대로 일부 변형하여 측정하였다. 시료액 $5 \mathrm{~mL}$ 에 중성 formalin( $\mathrm{pH} 8.3)$ $10 \mathrm{~mL}$ 과 증류수 $10 \mathrm{~mL}$ 을 넣어 $0.1 \mathrm{~N} \mathrm{NaOH}$ 로 $\mathrm{pH} 8.4$ 가 될 때까지 중화하기 위해 적정하였다. 이때 소모된 $0.1 \mathrm{~N}$ $\mathrm{NaOH} \mathrm{mL}$ 수를 아미노태 질소함량으로 결정하였다. 대조 구는 중성 formalin을 대신하여 증류수를 사용하여 측정하 였다.

\section{암모니아태 질소}

암모니아태 질소 $\left(\mathrm{NH}_{4}-\mathrm{N}\right)$ 는 시료액 $0.1 \mathrm{~mL}$ 에 $\mathrm{A}$ 용액과 $\mathrm{B}$ 용액을 각각 $2 \mathrm{~mL}$ 씩 차례로 넣고 $37^{\circ} \mathrm{C}$ 에서 20 분간 반응시 켜 spectrophotometer(Libra S35, Biochrome Ltd.)를 이용하 여 $630 \mathrm{~nm}$ 에서 흡광도를 측정하였다. 황산암모늄 $\left(\left(\mathrm{NH}_{4}\right)_{2} \mathrm{SO}_{4}\right)$ 을 표준물질로 하여 작성한 검량곡선으로부터 암모니아태 질소 함량 $(\mathrm{mg} \%)$ 을 계산하였다(A용액: $10 \mathrm{~g}$, phenol and $0.05 \mathrm{~g}$ sodium nitroprusside dehydrate in 1,000 $\mathrm{mL}$ distilled water ; $\mathrm{B}$ 용액: $9 \mathrm{~g} \mathrm{Na}_{2} \mathrm{HPO}_{4} \cdot 12 \mathrm{H}_{2} \mathrm{O}, 6 \mathrm{~g} \mathrm{NaOH}$ and $10 \mathrm{~mL} \mathrm{NaOCl}$ in $1,000 \mathrm{~mL}$ distilled water).

\section{미생물수}

된장 $1 \mathrm{~g}$ 에 $0.85 \%(\mathrm{w} / \mathrm{v})$ 생리식염수 $9 \mathrm{~mL}$ 을 시험관에 담아 균질화시키고 이를 십진희석법으로 희석하여 총균수 는 tryptic soy agar(BD Difco Lab., Detroit, MI, USA), 유산균 수는 lactobacilli MRS agar(BD Difco Lab.)배지를 이용하여 접종 도말하였다. 총균수는 $37^{\circ} \mathrm{C}$ 에서 24 시간 동안 호기배 양을, 유산균수는 48-72시간 동안 혐기배양한 후 형성된
집락을 2회 반복 계수하여 $\log \mathrm{CFU} / \mathrm{g}$ 로 환산하여 표시하 였다.

\section{무기성분}

무기성분은 나트륨 $(\mathrm{Na})$, 칼륨(K), 마그네슘 $(\mathrm{Mg})$, 칼슘 $(\mathrm{Ca})$ 을 농업기술실용화재단에 의뢰하여 측정하였다. 무기 물 함량은 식품공전방법(28)에 준하여 검체를 고온에서 탄 화시켜 유기물질을 회화시킨 후 용해하여 유도결합플라즈 마법으로 측정하였다. 시료 $1 \mathrm{~g}$ 을 회화용기에 칭량하고 회 화로 $550^{\circ} \mathrm{C}$ 의 온도에서 여러 시간 가열하여 백색의 회분이 얻어질 때까지 회화하였다. 완전히 탄화된 회분을 방냉 후 약 $10 \mathrm{~mL}$ 의 염산용액 $\left(\mathrm{HCl}: \mathrm{H}_{2} \mathrm{O}=1: 1, \mathrm{v} / \mathrm{v}\right)$ 을 가해 수욕상에 서 완전 증발 건조시켜 이 건조물에 염산용액 약 $10 \mathrm{~mL}$ 를 가하여 30 분간 용해하고 $50 \mathrm{~mL}$ 메스플라스크에 여과·정용 하여 시험용액으로 사용하였다. 시험용액은 ICP-OES(Optima 8300, Perkin elmer Co., Shelton, CT, USA)로 칼슘, 나트륨, 칼륨, 마그네슘을 측정하였다. 이 때 RF Power는 $1,300 \mathrm{~W}$, Plasma Argon gas flow rate $15 \mathrm{~L} / \mathrm{min}$, Auxiliary argon gas flow rate $0.2 \mathrm{~L} / \mathrm{min}$, Nebulizer argon gas flow rate $0.6 \mathrm{~L} / \mathrm{min}$ 으로 하였다.

\section{맛 센서 이용한 맛 분석}

발효기간에 따른 된장의 맛 변화를 살펴보기 위하여 맛 센서 분석기(TS-5000Z, Insent, Atsugi, Japan)를 이용하여 수행하였다. 된장 시료의 전처리는 각각의 샘플 $2 \mathrm{~g}$ 을 취해 증류수로 5 배 희석한 후 원심 분리하여 얻은 상등액을 여과 하여 시료로 사용하였다. 맛 센서 분석기에 시료를 $70 \mathrm{~mL}$ 씩 넣어 3회 반복 측정한 후, 평균값을 구하여 쓴맛(bitter), 짠맛(saltiness), 신맛(sourness), 감칠맛(umami), 떫은맛 (astringency)의 값을 객관적으로 나타내었다(21).

\section{통계처리}

모든 실험은 3회 반복 실험하여 평균과 표준편차로 나타 내었고, 실험값에 대한 통계분석은 SAS 9.2 program(SAS Institute Inc., Cary, NC, USA)을 이용하여 통계처리하였으 며, Duncan's multiple range test 방법과 t-test를 이용하여 평 균값 간에 유의수준 $\mathrm{p}<0.05$ 에서 유의성을 검정하였다.

\section{결과 및 고찰}

\section{수분 및 염도}

염수 침지 과정이 없는 콩알메주로 제조한 $8 \%$ 염도의 된장과 여기에 3 종의 염생식물 분말을 첨가하여 제조한 된장을 6개월 동안 발효하면서 품질특성을 비교하였다. Table 2에 된장의 수분 함량 및 염도의 변화를 나타내었다. 수분 함량에서는 염생식물 분말을 첨가하지 않은 된장 
Table 2. Change in moisture and salinity of Doenjang by adding halophytes during fermentation period

\begin{tabular}{|c|c|c|c|c|c|c|c|c|c|c|}
\hline \multirow{2}{*}{ Contents } & \multirow{2}{*}{$\begin{array}{l}\text { Doenjang } \\
\text { group }\end{array}$} & \multirow{2}{*}{$\begin{array}{c}\text { Powder } \\
(\%)\end{array}$} & \multicolumn{8}{|c|}{ Fermentation period (week) } \\
\hline & & & 0 & 2 & 4 & 8 & 12 & 16 & 20 & 24 \\
\hline \multirow{7}{*}{$\begin{array}{c}\text { Moisture } \\
(\%)\end{array}$} & Control & & $57.4 \pm 0.5^{1) \mathrm{Aa} 2)}$ & $57.0 \pm 0.2^{\mathrm{Ba}}$ & $55.5 \pm 0.4^{\mathrm{Cb}}$ & $55.8 \pm 0.0^{\mathrm{Ca}}$ & $54.4 \pm 0.2^{\mathrm{Da}}$ & $53.9 \pm 0.1^{\mathrm{Ec}}$ & $53.9 \pm 0.2^{\mathrm{Db}}$ & $54.0 \pm 0.0^{\mathrm{DEc}}$ \\
\hline & \multirow{2}{*}{ Salicornia europaea } & 5 & $55.6 \pm 0.7^{\mathrm{Abc}}$ & $55.0 \pm 0.0^{\mathrm{ABc}}$ & $54.4 \pm 0.2^{\mathrm{BCd}}$ & $54.6 \pm 0.3^{\mathrm{BCcd}}$ & $52.9 \pm 0.1^{\mathrm{Ec}}$ & $54.2 \pm 0.6^{\mathrm{CDbc}}$ & $52.9 \pm 0.6^{\mathrm{Ed}}$ & $53.7 \pm 0.1^{\mathrm{Dd}}$ \\
\hline & & 10 & $55.2 \pm 0.2^{\mathrm{Acd}}$ & $54.3 \pm 0.1^{\mathrm{Bd}}$ & $53.9 \pm 0.1^{\mathrm{Ce}}$ & $54.4 \pm 0.1^{\mathrm{Bd}}$ & $52.0 \pm 0.1^{\mathrm{Fd}}$ & $53.1 \pm 0.2^{\mathrm{Ed}}$ & $53.1 \pm 0.0^{\mathrm{Ed}}$ & $53.5 \pm 0.1^{\mathrm{De}}$ \\
\hline & \multirow{2}{*}{ Suaeda japonica } & 5 & $57.5 \pm 0.2^{\mathrm{Aa}}$ & $55.9 \pm 0.4^{\mathrm{Bb}}$ & $56.1 \pm 0.1^{\mathrm{Ba}}$ & $55.1 \pm 0.5^{\mathrm{Cb}}$ & $53.6 \pm 0.3^{\mathrm{Db}}$ & $55.1 \pm 0.1^{\mathrm{Ca}}$ & $55.3 \pm 0.1^{\mathrm{Ca}}$ & $54.9 \pm 0.0^{\mathrm{Ca}}$ \\
\hline & & 10 & $56.1 \pm 0.6^{\mathrm{Ab}}$ & $54.6 \pm 0.4^{\mathrm{Bdd}}$ & $55.0 \pm 0.2^{\mathrm{Bc}}$ & $54.7 \pm 0.0^{\mathrm{Bbcd}}$ & $53.5 \pm 0.6^{\mathrm{Cb}}$ & $54.7 \pm 0.1^{\mathrm{Bab}}$ & $54.8 \pm 0.2^{\mathrm{Bb}}$ & $54.4 \pm 0.1^{\mathrm{Bb}}$ \\
\hline & \multirow{2}{*}{ Suaeda asparagoides } & 5 & $55.7 \pm 0.1^{\mathrm{Abc}}$ & $54.7 \pm 0.2^{\mathrm{Ccd}}$ & $55.2 \pm 0.1^{\mathrm{Bc}}$ & $54.8 \pm 0.0^{\mathrm{Cbc}}$ & $53.3 \pm 0.2^{\mathrm{Ebc}}$ & $54.2 \pm 0.4^{\mathrm{Dbc}}$ & $54.3 \pm 0.0^{\mathrm{Db}}$ & $54.2 \pm 0.1^{\mathrm{Db}}$ \\
\hline & & 10 & $54.5 \pm 0.4^{\mathrm{Ad}}$ & $53.6 \pm 0.5^{\mathrm{BCe}}$ & $54.4 \pm 0.0^{\mathrm{Ad}}$ & $53.8 \pm 0.0^{\mathrm{Be}}$ & $53.4 \pm 0.0^{\mathrm{Cb}}$ & $54.3 \pm 0.2^{\mathrm{Abc}}$ & $53.7 \pm 0.1^{\mathrm{BCc}}$ & $53.6 \pm 0.0^{\mathrm{BCde}}$ \\
\hline \multirow{7}{*}{$\begin{array}{c}\text { Salinity } \\
(\%)\end{array}$} & Control & & $8.7 \pm 0.1^{\mathrm{Aa}}$ & $8.2 \pm 0.0^{\mathrm{Ba}}$ & $8.0 \pm 0.0^{\mathrm{Ccd}}$ & $8.2 \pm 0.1^{\mathrm{BCabc}}$ & $7.9 \pm 0.0^{\mathrm{Dab}}$ & $8.1 \pm 0.0^{\mathrm{BCb}}$ & $8.1 \pm 0.1^{\mathrm{BCc}}$ & $8.2 \pm 0.0^{\mathrm{Bb}}$ \\
\hline & \multirow{2}{*}{ Salicornia europaea } & 5 & $8.5 \pm 0.0^{\mathrm{Ab}}$ & $8.2 \pm 0.1^{\mathrm{CDa}}$ & $8.3 \pm 0.0^{\mathrm{BCb}}$ & $8.0 \pm 0.1^{\mathrm{Ed}}$ & $8.0 \pm 0.2^{\mathrm{DEa}}$ & $8.3 \pm 0.0^{\mathrm{ABCa}}$ & $8.4 \pm 0.1^{\mathrm{ABa}}$ & $8.4 \pm 0.0^{\mathrm{ABa}}$ \\
\hline & & 10 & $8.5 \pm 0.1^{\mathrm{Ab}}$ & $8.1 \pm 0.1^{\mathrm{DEa}}$ & $8.4 \pm 0.0^{\mathrm{ABa}}$ & $8.2 \pm 0.1^{\mathrm{CDab}}$ & $7.9 \pm 0.2^{\mathrm{Fab}}$ & $8.3 \pm 0.1^{\mathrm{BCa}}$ & $8.0 \pm 0.0^{\mathrm{EFc}}$ & $8.1 \pm 0.0^{\mathrm{DEbc}}$ \\
\hline & \multirow{2}{*}{ Suaeda japonica } & 5 & $8.3 \pm 0.0^{\mathrm{Ac}}$ & $8.2 \pm 0.1^{\mathrm{ABa}}$ & $8.0 \pm 0.0^{\mathrm{Cd}}$ & $8.3 \pm 0.0^{\mathrm{ABa}}$ & $7.7 \pm 0.0^{\mathrm{Db}}$ & $8.2 \pm 0.1^{\mathrm{ABab}}$ & $8.0 \pm 0.0^{\mathrm{Cc}}$ & $8.2 \pm 0.1^{\mathrm{Bb}}$ \\
\hline & & 10 & $8.2 \pm 0.1^{\mathrm{Ac}}$ & $8.3 \pm 0.1^{\mathrm{Aa}}$ & $8.1 \pm 0.0^{\mathrm{BCc}}$ & $8.0 \pm 0.1^{\mathrm{Ccd}}$ & $7.7 \pm 0.1^{\mathrm{Db}}$ & $8.2 \pm 0.1^{\mathrm{ABab}}$ & $8.0 \pm 0.0^{\mathrm{Cc}}$ & $8.0 \pm 0.0^{\mathrm{Cd}}$ \\
\hline & \multirow{2}{*}{ Suaeda asparagoides } & 5 & $8.3 \pm 0.0^{\mathrm{Ac}}$ & $7.9 \pm 0.1^{\mathrm{cb}}$ & $7.9 \pm 0.1^{\mathrm{Ce}}$ & $8.1 \pm 0.1^{\mathrm{ABbc}}$ & $7.9 \pm 0.2^{\mathrm{Cab}}$ & $8.1 \pm 0.1^{\mathrm{ABb}}$ & $8.3 \pm 0.0^{\mathrm{Ab}}$ & $8.1 \pm 0.1^{\mathrm{BCc}}$ \\
\hline & & 10 & $8.3 \pm 0.0^{\mathrm{Ac}}$ & $8.1 \pm 0.1^{\mathrm{BCa}}$ & $8.0 \pm 0.0^{\mathrm{Dde}}$ & $8.2 \pm 0.1^{\mathrm{ABab}}$ & $7.4 \pm 0.1^{\mathrm{Fc}}$ & $8.1 \pm 0.1^{\mathrm{BCDb}}$ & $7.8 \pm 0.1^{\mathrm{Ed}}$ & $8.1 \pm 0.1^{\mathrm{CDcd}}$ \\
\hline
\end{tabular}

${ }^{1)}$ Means \pm SD ( $\mathrm{n}=3$ ) within each column followed by the same letter are not significantly different $(\mathrm{p}<0.05)$.

${ }^{2)}$ Value with different superscripts within the same column $(\mathrm{A}-\mathrm{H})$ or row $(\mathrm{a}-\mathrm{g})$ are significantly different by ANOVA with Duncan's multiple range test at $\mathrm{p}<0.05$.

Table 3. Change in $\mathrm{pH}$ and titratable acidity of Doenjang by adding halophytes during fermentation period

\begin{tabular}{|c|c|c|c|c|c|c|c|c|c|c|}
\hline \multirow{2}{*}{ Contents } & \multirow{2}{*}{$\begin{array}{l}\text { Doenjang } \\
\text { group }\end{array}$} & \multirow{2}{*}{$\begin{array}{l}\text { Powder } \\
(\%)\end{array}$} & \multicolumn{8}{|c|}{ Fermentation period (week) } \\
\hline & & & 0 & 2 & 4 & 8 & 12 & 16 & 20 & 24 \\
\hline \multirow{7}{*}{$\mathrm{pH}$} & Control & & $6.3 \pm 0.0^{1) \mathrm{A} 22)}$ & $5.9 \pm 0.0^{\mathrm{Bd}}$ & $5.7 \pm 0.0^{\mathrm{Db}}$ & $5.6 \pm 0.0^{\mathrm{Ga}}$ & $5.6 \pm 0.0^{\mathrm{Fd}}$ & $5.7 \pm 0.0^{\mathrm{Cd}}$ & $5.6 \pm 0.0^{\mathrm{Ec}}$ & $5.6 \pm 0.0^{\mathrm{Fe}}$ \\
\hline & \multirow{2}{*}{ Salicornia europaea } & 5 & $6.3 \pm 0.0^{\mathrm{Ad}}$ & $5.7 \pm 0.0^{\mathrm{Df}}$ & $5.6 \pm 0.0^{\mathrm{Gd}}$ & $5.5 \pm 0.0^{\mathrm{Hd}}$ & $5.7 \pm 0.0^{\mathrm{Fa}}$ & $5.7 \pm 0.0^{\mathrm{Eb}}$ & $5.8 \pm 0.0^{\mathrm{Ca}}$ & $6.1 \pm 0.0^{\mathrm{Ba}}$ \\
\hline & & 10 & $6.3 \pm 0.0^{\mathrm{Ac}}$ & $5.9 \pm 0.0^{\mathrm{Bc}}$ & $5.6 \pm 0.0^{\mathrm{Ec}}$ & $5.6 \pm 0.0^{\mathrm{Gb}}$ & $5.7 \pm 0.0^{\mathrm{Db}}$ & $5.8 \pm 0.0^{\mathrm{Ca}}$ & $5.6 \pm 0.0^{\mathrm{Fd}}$ & $5.8 \pm 0.0^{\mathrm{Cc}}$ \\
\hline & \multirow{2}{*}{ Suaeda japonica } & 5 & $6.2 \pm 0.0^{\mathrm{Ae}}$ & $5.8 \pm 0.0^{\mathrm{Ce}}$ & $5.7 \pm 0.0^{\mathrm{Fb}}$ & $5.5 \pm 0.0^{\mathrm{Hc}}$ & $5.6 \pm 0.0^{\mathrm{Gc}}$ & $5.7 \pm 0.0^{\mathrm{Dc}}$ & $5.7 \pm 0.0^{\mathrm{Eb}}$ & $5.9 \pm 0.0^{\mathrm{Bb}}$ \\
\hline & & 10 & $6.1 \pm 0.0^{\mathrm{Ag}}$ & $5.7 \pm 0.0^{\mathrm{Bg}}$ & $5.6 \pm 0.0^{\mathrm{Dd}}$ & $5.5 \pm 0 . .^{\mathrm{Ff}}$ & $5.5 \pm 0.0^{\mathrm{Ge}}$ & $5.6 \pm 0.0^{\mathrm{De}}$ & $5.6 \pm 0 . .^{\mathrm{Ee}}$ & $5.6 \pm 0.0^{\mathrm{Cd}}$ \\
\hline & \multirow{2}{*}{ Suaeda asparagoides } & 5 & $6.2 \pm 0.0^{\mathrm{Af}}$ & $6.1 \pm 0.0^{\mathrm{Ba}}$ & $5.5 \pm 0.0^{\mathrm{Ee}}$ & $5.4 \pm 0.0^{\mathrm{Hg}}$ & $5.4 \pm 0.0^{\mathrm{Gg}}$ & $5.5 \pm 0.0^{\mathrm{Ff}}$ & $5.5 \pm 0.0^{\mathrm{Cf}}$ & $5.5 \pm 0.0^{\mathrm{Df}}$ \\
\hline & & 10 & $6.3 \pm 0.0^{\mathrm{Ab}}$ & $6.0 \pm 0.0^{\mathrm{Bb}}$ & $5.7 \pm 0.0^{\mathrm{Ca}}$ & $5.5 \pm 0.0^{\mathrm{De}}$ & $5.5 \pm 0.0^{\mathrm{Ef}}$ & $5.4 \pm 0.0^{\mathrm{Fg}}$ & $5.4 \pm 0.0^{\mathrm{Gg}}$ & $5.3 \pm 0.0^{\mathrm{Hg}}$ \\
\hline \multirow{7}{*}{$\begin{array}{c}\text { Titratable acidity } \\
(\%)\end{array}$} & Control & & $1.4 \pm 0.0^{\mathrm{Fa}}$ & $1.7 \pm 0.0^{\mathrm{Ea}}$ & $2.3 \pm 0.0^{\mathrm{Ba}}$ & $2.4 \pm 0.1^{\mathrm{Aa}}$ & $2.4 \pm 0.0^{\mathrm{Aa}}$ & $2.4 \pm 0.0^{\mathrm{Aa}}$ & $2.0 \pm 0.0^{\mathrm{Ca}}$ & $1.9 \pm 0.0^{\mathrm{Da}}$ \\
\hline & \multirow{2}{*}{ Salicornia europaea } & 5 & $1.1 \pm 0.0^{\mathrm{Ge}}$ & $1.8 \pm 0.0^{\mathrm{DEa}}$ & $1.9 \pm 0.0^{\mathrm{Cc}}$ & $2.3 \pm 0.1^{\mathrm{Ab}}$ & $2.2 \pm 0.0^{\mathrm{Bb}}$ & $1.8 \pm 0.0^{\mathrm{Dc}}$ & $1.7 \pm 0.0^{\mathrm{Ee}}$ & $1.3 \pm 0.0^{\mathrm{Ff}}$ \\
\hline & & 10 & $1.2 \pm 0.0^{\mathrm{Gcd}}$ & $1.6 \pm 0.0^{\mathrm{Eb}}$ & $1.8 \pm 0.00^{\mathrm{Cd}}$ & $2.1 \pm 0.0^{\mathrm{Ac}}$ & $2.0 \pm 0.00^{\mathrm{Bc}}$ & $1.8 \pm 0.0^{\mathrm{Dd}}$ & $1.8 \pm 0.0^{\mathrm{Dd}}$ & $1.4 \pm 0.0^{\mathrm{Fe}}$ \\
\hline & \multirow{2}{*}{ Suaeda japonica } & 5 & $1.3 \pm 0.0^{\mathrm{Fd}}$ & $1.4 \pm 0.0^{\mathrm{Db}}$ & $2.0 \pm 0.0^{\mathrm{Ce}}$ & $2.3 \pm 0.0^{\mathrm{Aa}}$ & $1.9 \pm 0.0^{\mathrm{Be}}$ & $2.0 \pm 0.0^{\mathrm{Ccd}}$ & $1.9 \pm 0.0^{\mathrm{Cde}}$ & $1.8 \pm 0.0^{\mathrm{Ef}}$ \\
\hline & & 10 & $1.2 \pm 0.0^{\mathrm{Ec}}$ & $1.3 \pm 0.1^{\mathrm{Db}}$ & $1.8 \pm 0.0^{\mathrm{Cf}}$ & $2.1 \pm 0.0^{\mathrm{Ac}}$ & $1.9 \pm 0.0^{\mathrm{Be}}$ & $1.7 \pm 0.0^{\mathrm{Cf}}$ & $1.8 \pm 0.0^{\mathrm{Cde}}$ & $1.8 \pm 0.0^{\mathrm{Dd}}$ \\
\hline & \multirow{2}{*}{ Suaeda asparagoides } & 5 & $1.2 \pm 0.0^{\mathrm{Fb}}$ & $1.6 \pm 0.0^{\mathrm{Ec}}$ & $1.8 \pm 0.1^{\mathrm{Bb}}$ & $2.4 \pm 0.1^{\mathrm{Ab}}$ & $1.8 \pm 0.0^{\mathrm{Cd}}$ & $1.8 \pm 0.0^{\mathrm{Bb}}$ & $1.8 \pm 0.0^{\mathrm{Cb}}$ & $1.3 \pm 0.0^{\mathrm{Db}}$ \\
\hline & & 10 & $1.2 \pm 0.0^{\mathrm{Gd}}$ & $1.5 \pm 0.0^{\mathrm{Fd}}$ & $1.7 \pm 0.0^{\mathrm{Cd}}$ & $2.0 \pm 0.0^{\mathrm{Ac}}$ & $1.8 \pm 0.0^{\mathrm{Bd}}$ & $1.7 \pm 0.0^{\mathrm{Ee}}$ & $1.7 \pm 0.0^{\mathrm{Dc}}$ & $1.5 \pm 0.0^{\mathrm{Ec}}$ \\
\hline
\end{tabular}

${ }^{1)}$ Means \pm SD ( $\mathrm{n}=3$ ) within each column followed by the same letter are not significantly different $(\mathrm{p}<0.05)$.

${ }^{2)}$ Value with different superscripts within the same column (A-H) or row (a-g) are significantly different by ANOVA with Duncan's multiple range test at $\mathrm{p}<0.05$.

(57.4 $\pm 0.5 \%)$ 과 칠면초를 첨가한 된장(56.1 $\pm 0.6-57.5 \pm 0.2 \%)$ 에서 담금 직후 수분 함량이 높게 나타났으나, 발효 후에는 모든 된장에서 $53.5-54.9 \%$ 로 큰 차이를 나타내지 않았다.또 한 발효초기에는 염생식물 분말의 함량이 높을수록 된장의 수분 함량은 낮은 경향을 나타내었는데, 염생식물 분말의
종류에 따라서는 칠면초, 나문재, 함초 순으로 수분 함량이 낮게 나타났다. 본 실험에서는 염수 침지 과정 없이 콩알메 주에 소금과 물을 배합하여 된장을 제조하므로 전통된장의 수분함량을 $60 \%$ 이하로 규정하는 전통식품규격기준(30)에 부합하여 선행연구에서 염수침지 과정을 거치는 재래 
Table 4. Change in color of Doenjang by adding halophytes during fermentation period

\begin{tabular}{|c|c|c|c|c|c|c|c|c|c|c|}
\hline \multirow{2}{*}{ Items } & \multirow{2}{*}{$\begin{array}{c}\text { Doenjang } \\
\text { group }\end{array}$} & \multirow{2}{*}{$\begin{array}{c}\text { Powder } \\
(\%)\end{array}$} & \multicolumn{8}{|c|}{ Fermentation period (week) } \\
\hline & & & 0 & 2 & 4 & 8 & 12 & 16 & 20 & 24 \\
\hline \multirow{7}{*}{$\mathrm{L}$} & Control & & $59.4 \pm 0.1^{1 \mathrm{AA} 2)}$ & $54.2 \pm 0.1^{\mathrm{Ba}}$ & $49.4 \pm 0.0^{\mathrm{Ca}}$ & $43.6 \pm 0.1^{\mathrm{Da}}$ & $41.7 \pm 0.1^{\mathrm{Ea}}$ & $37.0 \pm 0.3^{\mathrm{Ga}}$ & $38.2 \pm 0.2^{\mathrm{Fa}}$ & $34.0 \pm 0.1^{\mathrm{Hb}}$ \\
\hline & \multirow{2}{*}{ Salicornia europaea } & 5 & $50.8 \pm 0.0^{\mathrm{Ab}}$ & $46.4 \pm 0.1^{\mathrm{Bb}}$ & $42.7 \pm 0.1^{\mathrm{Cb}}$ & $41.5 \pm 0.0^{\mathrm{Db}}$ & $38.4 \pm 0.1^{\mathrm{Eb}}$ & $36.7 \pm 0.3^{\mathrm{Fab}}$ & $34.8 \pm 0.0^{\mathrm{Gb}}$ & $34.5 \pm 0.2^{\text {Ha }}$ \\
\hline & & 10 & $45.7 \pm 0.1^{\mathrm{Ac}}$ & $44.0 \pm 0.1^{\mathrm{Bc}}$ & $40.7 \pm 0.0^{\mathrm{Cc}}$ & $38.4 \pm 0.0^{\mathrm{Dd}}$ & $37.1 \pm 0.1^{\mathrm{Ec}}$ & $36.3 \pm 0.1^{\mathrm{Fb}}$ & $34.5 \pm 0.1^{\mathrm{Gc}}$ & $33.8 \pm 0.1^{\mathrm{Hb}}$ \\
\hline & \multirow{2}{*}{ Suaeda japonica } & 5 & $42.7 \pm 0.0^{\mathrm{Ad}}$ & $41.5 \pm 0.1^{\mathrm{Bd}}$ & $38.8 \pm 0.0^{\mathrm{Dd}}$ & $40.7 \pm 0.1^{\mathrm{Cc}}$ & $34.4 \pm 0.0^{\mathrm{Ee}}$ & $34.3 \pm 0.1^{\mathrm{Ed}}$ & $34.2 \pm 0.2^{\mathrm{Ed}}$ & $32.2 \pm 0.2^{\mathrm{Fd}}$ \\
\hline & & 10 & $38.4 \pm 0.3^{\mathrm{Ae}}$ & $37.5 \pm 0.0^{\mathrm{Bf}}$ & $37.8 \pm 0.0^{\mathrm{Be}}$ & $36.7 \pm 0.1^{\mathrm{Cf}}$ & $34.5 \pm 0.3^{\mathrm{De}}$ & $33.4 \pm 0.2^{\mathrm{Ee}}$ & $32.8 \pm 0.2^{\mathrm{Ff}}$ & $31.6 \pm 0.1^{\mathrm{Ge}}$ \\
\hline & \multirow{2}{*}{ Suaeda asparagoides } & 5 & $42.7 \pm 0.0^{\mathrm{Ad}}$ & $39.7 \pm 0.0^{\mathrm{Be}}$ & $37.8 \pm 0.1^{\mathrm{Ce}}$ & $37.6 \pm 0.2^{\mathrm{Ce}}$ & $36.5 \pm 0.2^{\mathrm{Dd}}$ & $35.1 \pm 0.1^{\mathrm{Ec}}$ & $33.9 \pm 0.2^{\mathrm{Fe}}$ & $33.0 \pm 0.1^{\mathrm{Gc}}$ \\
\hline & & 10 & $37.5 \pm 0.1^{\mathrm{Af}}$ & $35.2 \pm 0.0^{\mathrm{Cg}}$ & $37.3 \pm 0.1^{\mathrm{Af}}$ & $36.8 \pm 0.0^{\mathrm{Bf}}$ & $33.0 \pm 0.1^{\mathrm{Ef}}$ & $33.0 \pm 0.3^{\mathrm{Ef}}$ & $33.7 \pm 0.2^{\mathrm{De}}$ & $31.6 \pm 0.1^{\mathrm{Fe}}$ \\
\hline \multirow{7}{*}{$\mathrm{a}$} & Control & & $8.0 \pm 0.0^{\mathrm{Ha}}$ & $10.3 \pm 0.0^{\mathrm{Ea}}$ & $12.4 \pm 0.1^{\mathrm{Ba}}$ & $12.2 \pm 0.0^{\mathrm{Ca}}$ & $13.5 \pm 0.0^{\mathrm{Aa}}$ & $9.7 \pm 0.0^{\mathrm{Fa}}$ & $10.6 \pm 0.0^{\mathrm{Da}}$ & $8.4 \pm 0.1^{\mathrm{Ga}}$ \\
\hline & \multirow{2}{*}{ Salicornia europaea } & 5 & $6.4 \pm 0.0^{\mathrm{Eb}}$ & $7.0 \pm 0.0^{\mathrm{Db}}$ & $7.9 \pm 0.0^{\mathrm{Bb}}$ & $9.6 \pm 0.1^{\mathrm{Ab}}$ & $7.5 \pm 0.1^{\mathrm{cb}}$ & $8.0 \pm 0.1^{\mathrm{Bb}}$ & $7.0 \pm 0.0^{\mathrm{Db}}$ & $7.0 \pm 0.1^{\mathrm{Db}}$ \\
\hline & & 10 & $6.1 \pm 0.0^{\mathrm{Fc}}$ & $6.3 \pm 0.0^{\mathrm{Ec}}$ & $6.6 \pm 0.1^{\mathrm{Cc}}$ & $7.1 \pm 0.0^{\mathrm{Bd}}$ & $7.3 \pm 0.0^{\mathrm{Ac}}$ & $6.5 \pm 0.0^{\mathrm{Dc}}$ & $6.1 \pm 0.0^{\mathrm{Fc}}$ & $6.6 \pm 0.0^{\mathrm{Cc}}$ \\
\hline & \multirow{2}{*}{ Suaeda japonica } & 5 & $6.2 \pm 0.0^{\mathrm{Bc}}$ & $5.3 \pm 0.1^{\mathrm{Dd}}$ & $5.1 \pm 0.0^{\mathrm{Ee}}$ & $7.9 \pm 0.0^{\mathrm{Ac}}$ & $5.7 \pm 0.0^{\mathrm{Ce}}$ & $5.7 \pm 0.1^{\mathrm{Cd}}$ & $4.9 \pm 0.0^{\mathrm{Fd}}$ & $5.3 \pm 0.1^{\mathrm{Dd}}$ \\
\hline & & 10 & $5.4 \pm 0.2^{\mathrm{Ad}}$ & $4.6 \pm 0.0 \mathrm{Cf}$ & $5.4 \pm 0.1^{\mathrm{Ad}}$ & $4.7 \pm 0.0^{\mathrm{BCf}}$ & $3.3 \pm 0.1^{\mathrm{Eg}}$ & $4.2 \pm 0.1^{\mathrm{Df}}$ & $4.3 \pm 0.11^{\mathrm{Df}}$ & $4.8 \pm 0.1^{\mathrm{Be}}$ \\
\hline & \multirow{2}{*}{ Suaeda asparagoides } & 5 & $6.4 \pm 0.0^{\mathrm{Ab}}$ & $5.2 \pm 0.0^{\mathrm{Ce}}$ & $5.1 \pm 0.1^{\mathrm{CDe}}$ & $5.1 \pm 0.0^{\mathrm{CDe}}$ & $6.0 \pm 0.2^{\mathrm{Bd}}$ & $5.0 \pm 0.0^{\mathrm{De}}$ & $4.4 \pm 0.1^{\mathrm{Ee}}$ & $5.2 \pm 0.0^{\mathrm{Cd}}$ \\
\hline & & 10 & $4.7 \pm 0.1^{\mathrm{Be}}$ & $3.5 \pm 0.1^{\mathrm{Eg}}$ & $4.1 \pm 0.0^{\mathrm{Cf}}$ & $5.1 \pm 0.0^{\mathrm{Ae}}$ & $3.9 \pm 0.1^{\mathrm{Df}}$ & $3.6 \pm 0.0^{\mathrm{Eg}}$ & $3.9 \pm 0.00^{\mathrm{Dg}}$ & $3.3 \pm 0.1^{\mathrm{Ff}}$ \\
\hline \multirow{7}{*}{$\mathrm{b}$} & Control & & $24.6 \pm 0.1^{\mathrm{Aa}}$ & $24.5 \pm 0.0^{\mathrm{Aa}}$ & $22.2 \pm 0.1^{\mathrm{Ba}}$ & $18.0 \pm 0.1^{\mathrm{Ca}}$ & $17.7 \pm 0.2^{\mathrm{Da}}$ & $12.1 \pm 0.1^{\mathrm{Fa}}$ & $13.1 \pm 0.2^{\mathrm{Ea}}$ & $9.0 \pm 0.1^{\mathrm{Gb}}$ \\
\hline & \multirow{2}{*}{ Salicornia europaea } & 5 & $20.5 \pm 0.0^{\mathrm{Ab}}$ & $17.5 \pm 0.0^{\mathrm{Bb}}$ & $15.5 \pm 0.0^{\mathrm{Db}}$ & $16.3 \pm 0.2^{\mathrm{Cb}}$ & $11.5 \pm 0.2^{\mathrm{Eb}}$ & $11.5 \pm 0.3^{\mathrm{Eb}}$ & $9.3 \pm 0.0^{\mathrm{Fb}}$ & $9.0 \pm 0.0^{\mathrm{Gb}}$ \\
\hline & & 10 & $15.4 \pm 0.1^{\mathrm{Bc}}$ & $15.8 \pm 0.1^{\mathrm{Ac}}$ & $13.4 \pm 0.0^{\mathrm{Cc}}$ & $13.4 \pm 0.0^{\mathrm{Cd}}$ & $11.6 \pm 0.1^{\mathrm{Db}}$ & $10.5 \pm 0.1^{\mathrm{Ec}}$ & $9.0 \pm 0.1^{\mathrm{Gc}}$ & $10.0 \pm 0.0^{\mathrm{Fa}}$ \\
\hline & \multirow{2}{*}{ Suaeda japonica } & 5 & $11.8 \pm 0.0^{\mathrm{De}}$ & $13.4 \pm 0.0^{\mathrm{Bd}}$ & $12.6 \pm 0.0^{\mathrm{Cd}}$ & $15.1 \pm 0.1^{\mathrm{Ac}}$ & $10.2 \pm 0.1^{\mathrm{Ed}}$ & $9.5 \pm 0.1^{\mathrm{Fd}}$ & $7.8 \pm 0.2^{\mathrm{Gd}}$ & $7.0 \pm 0.1^{\mathrm{He}}$ \\
\hline & & 10 & $7.6 \pm 0.1^{\mathrm{Gg}}$ & $10.4 \pm 0.0^{\mathrm{Cf}}$ & $11.5 \pm 0.0^{\mathrm{Ae}}$ & $10.9 \pm 0.1^{\mathrm{Be}}$ & $7.1 \pm 0.1^{\mathrm{Hf}}$ & $8.2 \pm 0.1^{\mathrm{Df}}$ & $7.8 \pm 0.1^{\mathrm{Fd}}$ & $8.0 \pm 0.1^{\mathrm{Ed}}$ \\
\hline & \multirow{2}{*}{ Suaeda asparagoides } & 5 & $14.2 \pm 0.0^{\mathrm{Ad}}$ & $11.9 \pm 0.0^{\mathrm{Be}}$ & $10.5 \pm 0.1^{\mathrm{Cf}}$ & $10.3 \pm 0.2^{\mathrm{Cf}}$ & $10.6 \pm 0.3^{\mathrm{Cc}}$ & $8.7 \pm 0.11^{\mathrm{De}}$ & $7.3 \pm 0.2^{\mathrm{Fe}}$ & $8.4 \pm 0.1^{\mathrm{Ec}}$ \\
\hline & & 10 & $8.5 \pm 0.0^{\mathrm{Bf}}$ & $8.0 \pm 0.1^{\mathrm{Cg}}$ & $8.4 \pm 0.1^{\mathrm{Bg}}$ & $9.5 \pm 0.0^{\mathrm{Ag}}$ & $7.7 \pm 0.00^{\mathrm{De}}$ & $6.3 \pm 0.1^{\mathrm{Eg}}$ & $5.7 \pm 0.1^{\mathrm{Ff}}$ & $4.8 \pm 0.0^{\text {Gf }}$ \\
\hline \multirow{7}{*}{$\Delta \mathrm{E}$} & Control & & $48.2 \pm 0.0^{\mathrm{Hg}}$ & $53.0 \pm 0.1^{\mathrm{Gg}}$ & $56.6 \pm 0.0^{\mathrm{Ff}}$ & $60.5 \pm 0.1^{\mathrm{Ef}}$ & $62.4 \pm 0.1^{\mathrm{Dg}}$ & $64.9 \pm 0.3^{\mathrm{Bd}}$ & $64.1 \pm 0.2^{\mathrm{Cd}}$ & $67.2 \pm 0.2^{\mathrm{Ae}}$ \\
\hline & \multirow{2}{*}{ Salicornia europaea } & 5 & $53.7 \pm 0.0^{\mathrm{Gf}}$ & $56.9 \pm 0.1^{\mathrm{Ff}}$ & $59.9 \pm 0.1^{\mathrm{Ee}}$ & $61.5 \pm 0.1^{\mathrm{De}}$ & $63.1 \pm 0.2^{\mathrm{Cf}}$ & $64.9 \pm 0.4^{\mathrm{Bd}}$ & $66.2 \pm 0.0^{\mathrm{Ac}}$ & $66.5 \pm 0.1^{\mathrm{Af}}$ \\
\hline & & 10 & $56.7 \pm 0.1^{\mathrm{He}}$ & $58.6 \pm 0.0^{\mathrm{Ge}}$ & $61.2 \pm 0.0^{\mathrm{Fd}}$ & $63.4 \pm 0.0^{\mathrm{Ec}}$ & $64.3 \pm 0.2^{\mathrm{De}}$ & $64.8 \pm 0.1^{\mathrm{Cd}}$ & $66.3 \pm 0.1^{\mathrm{Bbc}}$ & $67.3 \pm 0.1^{\mathrm{Ae}}$ \\
\hline & \multirow{2}{*}{ Suaeda japonica } & 5 & $58.8 \pm 0.0^{\mathrm{Gd}}$ & $60.3 \pm 0.1^{\mathrm{Fd}}$ & $62.7 \pm 0.0^{\mathrm{Dc}}$ & $61.7 \pm 0.0^{\mathrm{Ed}}$ & $66.6 \pm 0.0^{\mathrm{BCb}}$ & $66.6 \pm 0.1^{\mathrm{Bb}}$ & $66.4 \pm 0.3^{\mathrm{Cbc}}$ & $68.4 \pm 0.2^{\mathrm{Ac}}$ \\
\hline & & 10 & $62.3 \pm 0.2^{\mathrm{Gb}}$ & $63.5 \pm 0.0^{\mathrm{Fb}}$ & $63.5 \pm 0.0^{\mathrm{Fa}}$ & $64.4 \pm 0.11^{\mathrm{Ea}}$ & $66.1 \pm 0.3^{\mathrm{Dc}}$ & $67.3 \pm 0.2^{\mathrm{Ca}}$ & $67.7 \pm 0.2^{\mathrm{Ba}}$ & $69.0 \pm 0.1^{\mathrm{Aa}}$ \\
\hline & \multirow{2}{*}{ Suaeda asparagoides } & 5 & $59.4 \pm 0.0^{\mathrm{Gc}}$ & $61.7 \pm 0.0^{\mathrm{Fc}}$ & $63.3 \pm 0.1^{\mathrm{Eb}}$ & $63.5 \pm 0.3^{\mathrm{Ec}}$ & $64.7 \pm 0.2^{\mathrm{Dd}}$ & $65.7 \pm 0.1^{\mathrm{Cc}}$ & $66.6 \pm 0.2^{\mathrm{Bb}}$ & $67.7 \pm 0.1^{\mathrm{Ad}}$ \\
\hline & & 10 & $63.3 \pm 0.1^{\mathrm{Fa}}$ & $65.4 \pm 0.0^{\mathrm{Da}}$ & $63.4 \pm 0.1^{\mathrm{Fab}}$ & $64.2 \pm 0.0^{\mathrm{Eb}}$ & $67.5 \pm 0.1^{\mathrm{Ba}}$ & $67.4 \pm 0.3^{\mathrm{Ba}}$ & $66.6 \pm 0.2^{\mathrm{Cb}}$ & $68.7 \pm 0.1^{\mathrm{Ab}}$ \\
\hline
\end{tabular}

${ }^{1)}$ Means \pm SD ( $\left.n=3\right)$ within each column followed by the same letter are not significantly different $(\mathrm{p}<0.05)$.

${ }^{2)}$ Value with different superscripts within the same column $(\mathrm{A}-\mathrm{H})$ or row (a-g) are significantly different by ANOVA with Duncan's multiple range test at $\mathrm{p}<0.05$.

방식으로 제조한 저염된장에서 나타났던 수분함량이 $60 \%$ 이내라는 기준을 초과하는 문제가 해소될 수 있었다.

된장의 염도는 담금 초기에 8.3-8.7\%로 첨가된 소금과 염생식물의 양에 따라 조절되었으며, 발효 6개월 후에는 $8.0-8.4 \%$ 로 약간 감소하였으나 염생식물 분말 첨가와 발효 기간에 따른 염도의 변화는 그다지 크지 않은 것으로 판단 된다.

\section{$\mathrm{pH}$ 및 산도}

된장의 발효미생물의 대사로 인해 생성되는 유기산 함량 변화를 보여주는 $\mathrm{pH}$ 및 산도의 변화를 살펴본 후 Table 3 에 그 값을 제시하였다.
담금 직후의 $\mathrm{pH}$ 값은 6.1-6.3이었으며 발효가 진행되면 서 모든 된장에서 $\mathrm{pH}$ 값이 조금 감소하여 5.3-6.1의 값을 보였다. 특히, 염생식물 분말 첨가량이 $5 \%$ 인 된장보다 $10 \%$ 인 된장에서 발효 후에 유의적으로 더 낮은 $\mathrm{pH}$ 값을 보였다. 다른 염생식물과 다르게 나문재를 첨가한 경우에는 염생 식물 분말을 첨가하지 않은 대조군 $(5.6 \pm 0.0)$ 보다 조금 더 낮은 $\mathrm{pH}(5.3-5.5 \pm 0.0)$ 를 나타내는 경향을 보였다.

산도 변화는 발효가 진행되면서 8주 차에 최대값 (2.0-2.4\%)을 보였다가 감소하는 경향을 보였는데, 이는 숙 성기간(60일) 동안 $\mathrm{pH}$ 는 저하되고 산도는 증가하였다는 Chang(31) 등의 결과와 일치하였다. 발효 완료 시에 염생식 물 분말을 첨가하지 않은 된장은 $1.9 \%$, 함초와 칠면초 분말 
을 첨가한 된장은 $1.3-1.5 \%$ 의 값을 보인 반면 나문재 분말을 첨가한 된장은 $1.8 \%$ 의 산도값을 보였다. 이는 $\mathrm{pH}$ 값과 비교 했을 때, 나문재 분말 첨가 된장은 다른 염생식물 분말 첨가 된장보다 $\mathrm{pH}$ 가 낮게 나타나 상대적으로 산도 값이 높은 것으로 보인다. 이는 발효가 진행되면서 미생물의 대사와 밀접한 관련이 있으며 대사산물인 lactic acid 및 acetic acid 등의 유기산의 축적으로 인해 일어나는 현상으로(32), 나문 재 된장의 발효 후기에 유산균 수가 증가한 것과 관련이 있는 것으로 사료된다.

\section{색 도}

발효에 따른 된장의 색도 변화를 관찰하여 Table 4에 제시하였다. 명도(lightness, L)는 발효 초기에 염생식물 분 말을 첨가하지 않은 된장에서 높은 값(59.4 \pm 0.1$)$ 을 보였고 염생식물 분말 첨가 비율이 높은 된장에서 가장 낮은 값

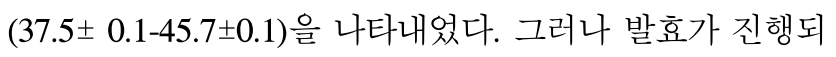
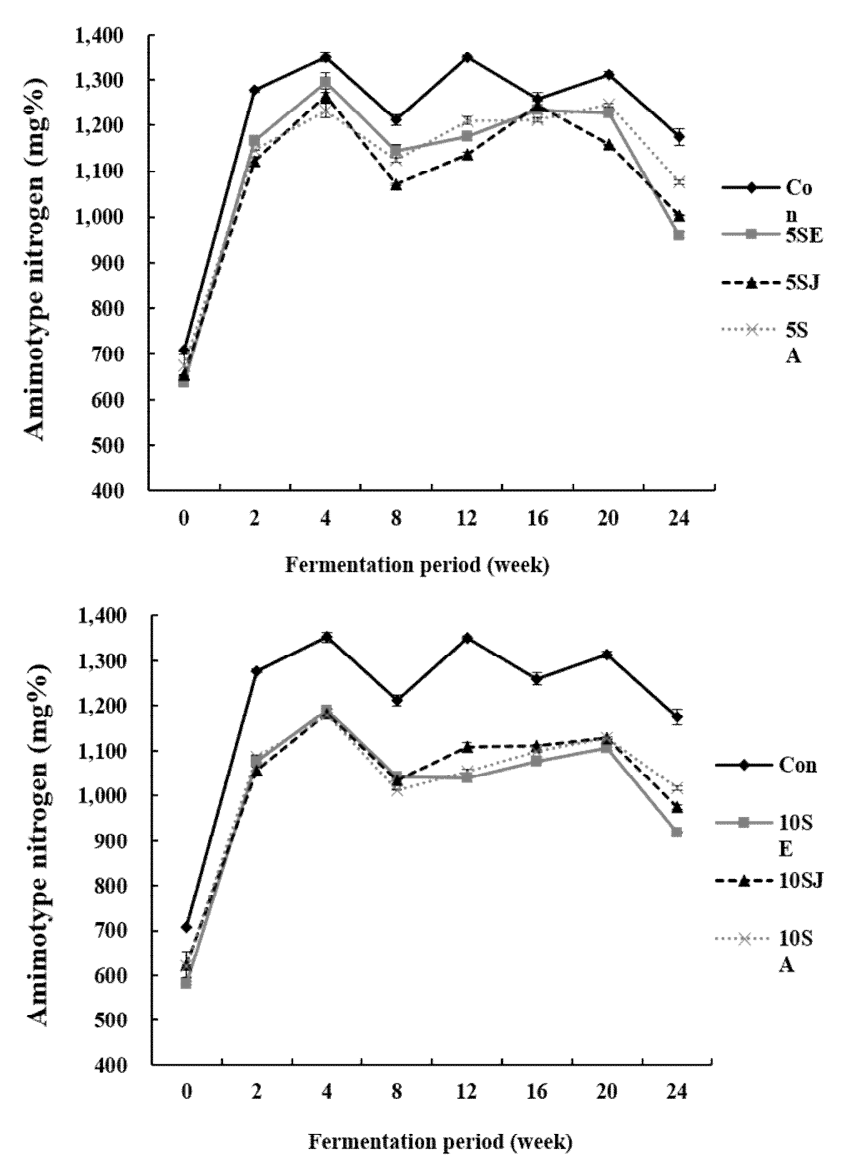

Fig. 1. Changes in amino-type nitrogen of Doenjang by adding halophytes during fermentation period.

Con, Doenjang without halophyte powder; 5SE, Doenjang with 5\% Salicornia europaea, 10SE, Doenjang with 10\% Salicornia europaea, 5SJ, Doenjang with 5\% Slaeda japonica, 10SJ, Doenjang with $10 \%$ Suaeda japonica, 5SA, Doenjang with 5\% Suaeda asparagoides, 10SA, Doenjang with $10 \%$ Suaeda asparagoides.
면서 모든 된장의 명도 값이 낮아져 시료 간에 비슷한 밝기 를 보였다(31.5 $\pm 0.1-34.5 \pm 0.2)$. 또한 적색도(redness, a) 값은 염생식물을 첨가하지 않은 된장에서 높은 값을 보였으며, 모든 된장에서 발효가 진행되면서 증가하다가 8 주 차 이후 로 감소하는 경향을 보였다. 황색도(yellowness, b)에서도 염생식물을 첨가하지 않은 된장에서 가장 높은 값을 나타냈 으며, 발효가 진행됨에 따라 점차 감소하는 경향을 확인하 였다. 된장의 색 변화를 변색도 $(\Delta \mathrm{E})$ 로 나타내었을 때 모든 된장은 발효가 진행되면서 점진적인 변화를 보였고, 특히 염생식물 분말을 첨가하지 않은 된장에서 색변화가 크게 나타났다. 이와 같은 된장의 갈변 현상은 Chang 등(31)이 보고한 바와 같이 된장에 함유되어 있는 tyrosine이 tyrosinase에 의해 melanoids를 형성하여 나타나는 효소적 갈변에 의한 것으로, 염생식물 분말의 고유 색깔 때문에 첨가여부에 따라 담금 초기에는 무첨가군과 첨가군 간의 색의 차이가 컸으나 발효가 완료된 후에는 모든 된장에서
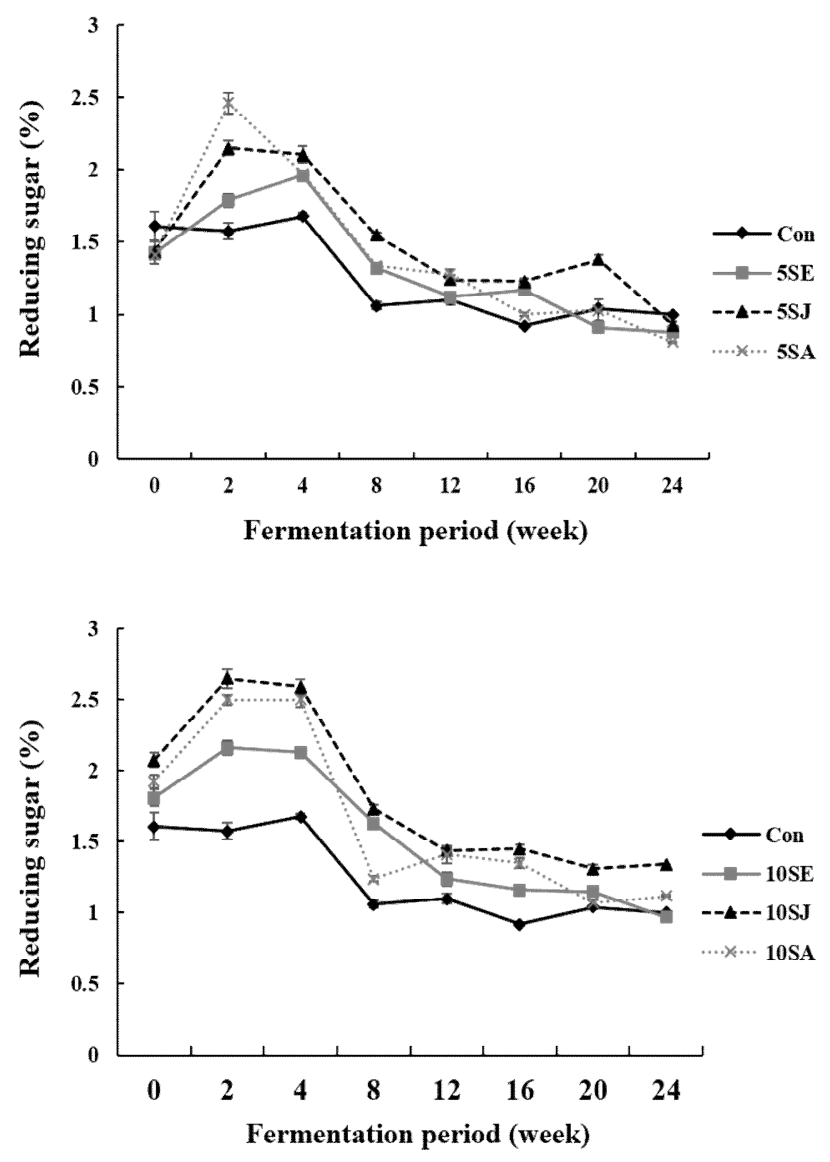

Fig 2. Change on reducing sugar of Doenjang by adding halophytes during fermentation period.

Con, Doenjang without halophyte powder; 5SE, Doenjang with 5\% Salicornia europaea; 10SE, Doenjang with 10\% Salicornia europaea, 5SJ, Doenjang with 5\% Suaeda japonica, 10SJ, Doenjang with 10\% Suaeda japonica, 5SA, Doenjang with 5\% Suaeda asparagoides, 10SA, Doenjang with $10 \%$ Suaeda asparagoides. 
Table 5. Total aerobic and lactic acid bacterial cell numbers of Doenjang by adding halophytes during fermentation period

\begin{tabular}{|c|c|c|c|c|c|c|c|}
\hline \multirow{2}{*}{ Bacterial group } & \multirow{2}{*}{$\begin{array}{l}\text { Doenjang } \\
\text { group }\end{array}$} & \multirow{2}{*}{$\begin{array}{c}\text { Powder } \\
(\%)\end{array}$} & \multicolumn{5}{|c|}{ Bacterial cell count (log CFU/g) during fermentation (week) } \\
\hline & & & 0 & 2 & 8 & 16 & 24 \\
\hline \multirow{7}{*}{ Aerobic bacteria } & Control & & $8.0 \pm 0.2^{1 \mathrm{Aa} 2)}$ & $7.8 \pm 0.0^{\mathrm{Ab}}$ & $7.8 \pm 0.2^{\mathrm{Aa}}$ & $7.8 \pm 0.1^{\mathrm{Aab}}$ & $7.8 \pm 0.0^{\mathrm{Aab}}$ \\
\hline & \multirow{2}{*}{ Salicornia europaea } & 5 & $8.0 \pm 0.2^{\mathrm{Aa}}$ & $7.9 \pm 0.0^{\mathrm{Aa}}$ & $7.8 \pm 0.0^{\mathrm{ABa}}$ & $7.6 \pm 0.0^{\mathrm{Bb}}$ & $7.6 \pm 0.0^{\mathrm{Bb}}$ \\
\hline & & 10 & $8.0 \pm 0.00^{A a}$ & $7.9 \pm 0.1^{\mathrm{ABab}}$ & $7.6 \pm 0.00^{\mathrm{Ca}}$ & $7.8 \pm 0.0^{\mathrm{Ba}}$ & $7.6 \pm 0.0^{\mathrm{Cb}}$ \\
\hline & \multirow{2}{*}{ Suaeda japonica } & 5 & $8.0 \pm 0.0^{\mathrm{Aa}}$ & $7.9 \pm 0.0^{\mathrm{ABCa}}$ & $7.8 \pm 0.0^{\mathrm{BCa}}$ & $7.7 \pm 0.2^{\mathrm{Cab}}$ & $8.0 \pm 0.1^{\mathrm{ABa}}$ \\
\hline & & 10 & $7.9 \pm 0.1^{\mathrm{Aa}}$ & $7.8 \pm 0.0^{\mathrm{ABab}}$ & $7.7 \pm 0.1^{\mathrm{Ba}}$ & $7.8 \pm 0.0^{\mathrm{Bab}}$ & $7.7 \pm 0.0^{\mathrm{Bb}}$ \\
\hline & \multirow{2}{*}{ Suaeda asparagoides } & 5 & $8.0 \pm 0.1^{\mathrm{Aa}}$ & $7.7 \pm 0.0^{\mathrm{Bac}}$ & $7.7 \pm 0.2^{\mathrm{ABa}}$ & $7.8 \pm 0.0^{\mathrm{ABab}}$ & $7.7 \pm 0.1^{\mathrm{Bb}}$ \\
\hline & & 10 & $7.9 \pm 0.1^{\mathrm{Aa}}$ & $7.8 \pm 0.1^{\mathrm{ABab}}$ & $7.6 \pm 0.3^{\mathrm{Ba}}$ & $7.8 \pm 0.0^{\mathrm{ABa}}$ & $7.7 \pm 0.1^{\mathrm{ABb}}$ \\
\hline \multirow{7}{*}{ Lactic acid bacteria } & Control & & $7.8 \pm 0.0^{\mathrm{Ab}}$ & $6.8 \pm 0.0^{\mathrm{Bb}}$ & $6.7 \pm 0.1^{\mathrm{Bab}}$ & $6.7 \pm 0.1^{\mathrm{Bab}}$ & $6.8 \pm 0.0^{\mathrm{Ba}}$ \\
\hline & \multirow{2}{*}{ Salicornia europaea } & 5 & $7.6 \pm 0.0^{\mathrm{Ac}}$ & $6.7 \pm 0.0^{\mathrm{BCb}}$ & $6.8 \pm 0.1^{\mathrm{Ba}}$ & $6.5 \pm 0.0^{\mathrm{cb}}$ & $6.6 \pm 0.1^{\mathrm{BCb}}$ \\
\hline & & 10 & $7.8 \pm 0.1^{\mathrm{Ab}}$ & $6.6 \pm 0.0^{\mathrm{Bc}}$ & $6.7 \pm 0.0^{\mathrm{Bab}}$ & $6.8 \pm 0.1^{\mathrm{Bab}}$ & $6.7 \pm 0.1^{\mathrm{Bab}}$ \\
\hline & \multirow{2}{*}{ Suaeda japonica } & 5 & $8.0 \pm 0.1^{\mathrm{Aa}}$ & $6.9 \pm 0.0^{\mathrm{Ba}}$ & $6.7 \pm 0.1^{\mathrm{Cab}}$ & $6.8 \pm 0.0^{\mathrm{Cab}}$ & $6.8 \pm 0.00^{\mathrm{Cab}}$ \\
\hline & & 10 & $7.8 \pm 0.00^{\mathrm{Ab}}$ & $6.7 \pm 0.0^{\mathrm{BCb}}$ & $6.8 \pm 0.2^{\mathrm{Ba}}$ & $6.5 \pm 0.0^{\mathrm{cb}}$ & $6.8 \pm 0.1^{\mathrm{Bab}}$ \\
\hline & \multirow{2}{*}{ Suaeda asparagoides } & 5 & $7.8 \pm 0.1^{\mathrm{Ab}}$ & $6.7 \pm 0.0^{\mathrm{Bb}}$ & $6.5 \pm 0.0^{\mathrm{Cb}}$ & $6.5 \pm 0.1^{\mathrm{cb}}$ & $6.7 \pm 0.0^{\mathrm{Bab}}$ \\
\hline & & 10 & $7.8 \pm 0.0^{\mathrm{Ab}}$ & $6.7 \pm 0.0^{\mathrm{Bb}}$ & $6.5 \pm 0.0^{\mathrm{cb}}$ & $6.7 \pm 0.1^{\mathrm{BCab}}$ & $6.7 \pm 0.1^{\mathrm{Bab}}$ \\
\hline
\end{tabular}

${ }^{1)}$ Means \pm SD ( $\left.n=3\right)$ within each column followed by the same letter are not significantly different $(\mathrm{p}<0.05)$.

${ }^{2}$ Value with different superscripts within the same column (A-C) or row (a-c) are significantly different by ANOVA with Duncan's multiple range test at $\mathrm{p}<0.05$.

는 비슷한 색을 띄는 것을 확인할 수 있었다. 이는 $\operatorname{Kim}(33)$ 등의 연구에서와 같이 첨가한 재료의 본래의 색소 등이 된장에 첨가될 때 영향을 준 것으로 판단된다.

\section{아미노태 질소}

염생식물을 첨가하여 제조한 된장의 아미노태 질소 함량 변화를 Fig. 1에 나타내었다. 담근 직후의 아미노태 질소 함량은 $582.4 \pm 2.8-707.0 \pm 1.4 \mathrm{mg} \%$ 였으며 된장이 발효 되면 서 증가되어 $918.9 \pm 2.14-1,174.6 \pm 18.2 \mathrm{mg} \%$ 함량값을 나타 내었다. 또한 염생식물 분말 첨가량에 따른 아미노태 질소 의 함량의 차이를 보였는데, 발효 후 된장의 염생식물 첨가 량을 $5 \%$ 로 첨가 시 함초는 $959.5 \pm 6.3 \mathrm{mg} \%$, 칠면초는 $1,003.8 \pm 1.4 \mathrm{mg} \%$, 나문재는 $1,076.1 \pm 4.9 \mathrm{mg} \%$ 으로 $10 \%$ 로 첨가하였을 때 함초는 $918.9 \pm 2.1 \mathrm{mg} \%$, 칠면초는 $973.5 \pm 4.9$ $\mathrm{mg} \%$, 나문재는 $1,015.5 \pm 4.9 \mathrm{mg} \%$ 으로 각각 약 $40,30,60$ $\mathrm{mg} \%$ 차이를 보였으나, 본 실험에서는 염생식물 무첨가 된장에 비해 아미노태질소 값이 그다지 높은 값을 나타내지 않았다. 이는 염생식물 첨가량에 따라 발효 중 미생물의 단백질분해력에 영향을 주어 값 차이를 보이는 것으로 사료 되어 아미노태질소량이 맛과 상관성이 높은 지표라고 간주 하였을 때 염생식물 첨가량을 좀 더 낮춰 비슷한 수준의 값을 나타낼 수 있는지 확인이 필요하다.

\section{환원당}

염생식물 첨가량을 달리하여 제조한 된장을 24 주 동안 발효하여 환원당 함량 변화를 확인하여 Fig. 2에 나타내었
다. 제조한 된장의 환원당 함량은 발효 2,4 주 차에 최대값 (1.7 $\pm 0.0-2.6 \pm 0.1 \%)$ 을 나타낸 후 점차 감소하였는데, 발효 초기에 환원당 함량이 높지만, 발효가 진행될수록 미생물 영양원 또는 알코올 발효 및 유기산 발효의 기질로 유리당 이 소모되어 환원당 함량이 감소되는 것으로 알려져 있다 (34). 염생식물 첨가에 따른 환원당 함량 변화는 아미노태 질소 함량과는 반대로 염생식물 무첨가군이 가장 낮은 값을 보이고 염생식물 분말의 첨가량이 높아질수록 환원당의 함량도 높아지는 경향을 보였으나 발효 후반에는 염생식물 첨가량에 관계없이 비슷한 수준을 유지하였다.

\section{미생물 변화}

된장은 다양한 미생물의 생육으로 인해 발효기간 동안 효소작용이 활발히 일어나 맛과 향을 비롯한 품질에 영향을 받는다. 이에 염생식물 분말을 첨가하여 제조한 된장의 발 효기간에 따라 미생물의 생육 변화를 확인해서 Table 5에 나타내었다.

총 균수는 담금 직후 7.9 $\pm 0.1-8.0 \pm 0.2 \log \mathrm{CFU} / \mathrm{g}$ 로 모든 된장이 비슷한 수를 보였으며 발효되면서 약간 감소하는 경향을 보이기는 하였으나 7.6 $\pm 0.0-8.0 \pm 0.1 \log \mathrm{CFU} / \mathrm{g}$ 로 염생식물 분말의 첨가 여부에 따른 차이를 나타내지 않았 다.

유산균은 증식하면서 생산한 유산과 nisin과 같은 물질에 의해 잡균이나 오염된 균의 증식을 방지하는 반면 과잉 생산된 젖산에 의한 산도 증가로 된장에 강한 신맛을 부여 하여 기호도에 영향을 준다(34). 담금 초기에는 7.6 $\pm 0.0-8.0 \pm$ 

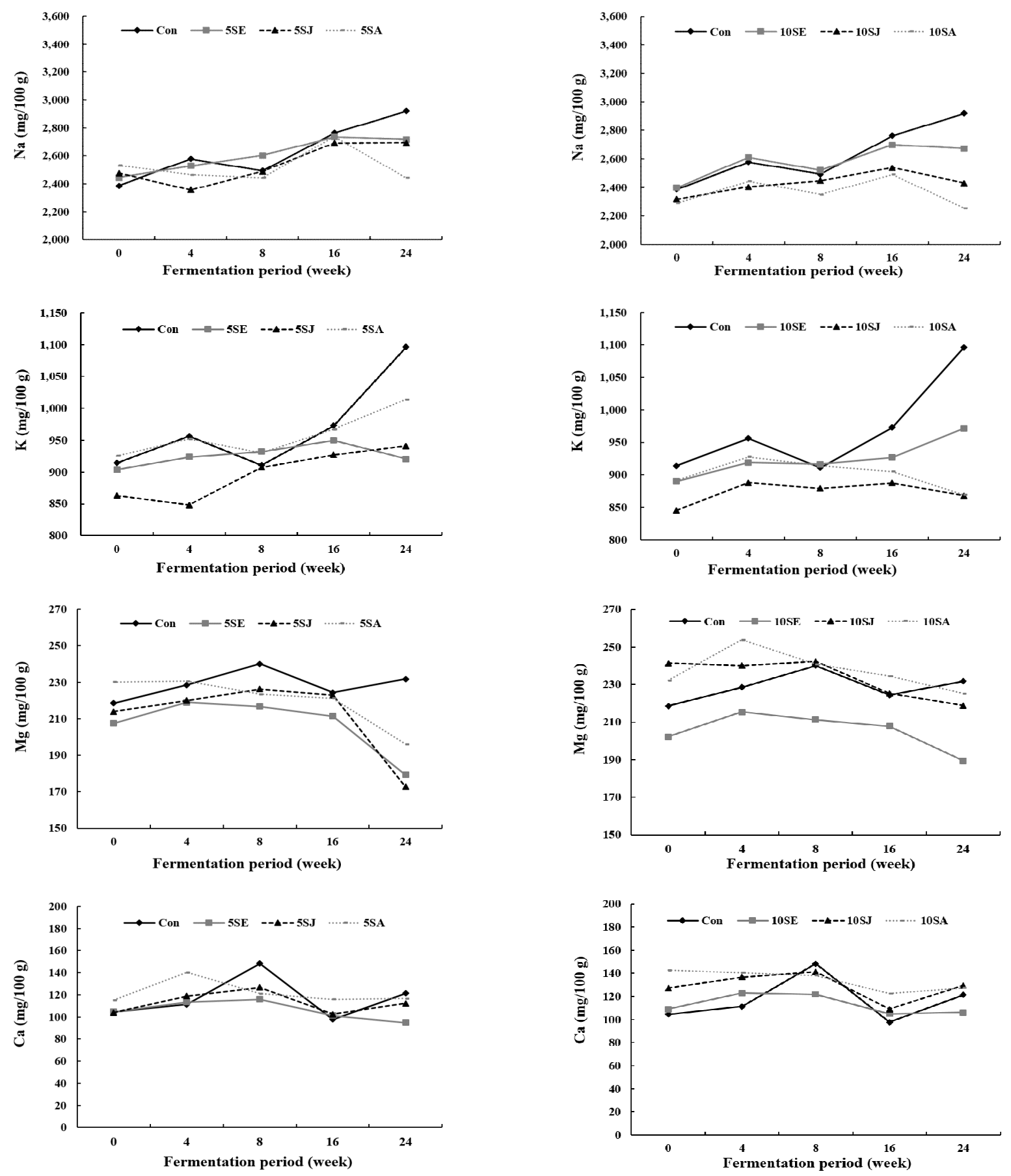

Fig 3. Change in mineral concentration of Doenjang by adding halophytes during fermentation period.

Con, Doenjang without halophyte powder; 5SE, Doenjang with 5\% Salicornia europaea, 10SE, Doenjang with 10\% Salicornia europaea; 5SJ, Doenjang with 5\% Suaeda japonica; 10SJ, Doenjang with $10 \%$ Suaeda japonica, 5SA, Doenjang with 5\% Suaeda asparagoides, 10SA, Doenjang with $10 \%$ Suaeda asparagoides.

$0.1 \log \mathrm{CFU} / \mathrm{g}$ 로 검출되었으나 발효 2주가 경과되면서 그 수가 6.6 $\pm 0.0-6.9 \pm 0.0 \log \mathrm{CFU} / \mathrm{g}$ 으로 급격히 감소한 후 발효 24 주 차까지 비슷한 수준을 나타내었다. 총 균수와 마찬가 지로 염생식물 분말의 첨가에 따른 유산균 수의 변화는 보이지 않았지만, 담금 직후에 비해 발효가 진행되면서 꾸 준히 유산균수가 감소하였다는 Lee 등(25)의 보고와 유
사한 경향을 나타내었다.

\section{무기 성분}

염생식물 분말을 첨가하여 제조한 된장의 발효기간에 따른 무기성분의 변화를 확인하여 Fig. 3에 나타내었다. 된장의 무기성분 함량을 분석한 결과, $\mathrm{Na}, \mathrm{K}, \mathrm{Mg}, \mathrm{Ca}$ 순으로 
높은 함량을 보였으며, 나트륨 $(\mathrm{Na})$ 은 발효 후 된장에서 염 생식물 분말 무첨가군에 비해 염생식물 첨가군에서 낮은 값을 나타내었으며, 특히 $10 \%$ 칠면초분말 첨가군은 $2,430.9 \mathrm{mg} / 100 \mathrm{~g}, 10 \%$ 나문재분말 첨가군은 $2,254.8$ $\mathrm{mg} / 100 \mathrm{~g}$ 으로 대조군의 $2,917.9 \mathrm{mg} / 100 \mathrm{~g}$ 보다 $17-22 \%$ 로 더 낮게 나타났다. 칼륨 $(\mathrm{K})$ 은 염생식물 무첨가군이 첨가군 에 비해 $124.7-228.4 \mathrm{mg} / 100 \mathrm{~g}$ 만큼 높은 값을 보였으며, 발효기간 동안 대체적으로 $5 \%$ 첨가군에서 더 높은 값을 보였다. $\mathrm{Mg}$ 은 발효 후에 무첨가군에 비해 $5 \%$ 첨가군에서 함량이 크게 낮아졌으며, $10 \%$ 첨가군에서는 칠면초와 나문 재 분말 첨가 된장에서는 무첨가군과 비슷한 함량값을, 함 초 분말 첨가 된장에서는 발효기간 동안 계속 낮은 함량값 을 보였다. 칼슘 $(\mathrm{Ca})$ 은 $5 \%$ 분말을 첨가한 된장에서 발효 후에 함초, 칠면초, 나문재가 각각 $94.91,112.14,116.75$ $\mathrm{mg} / 100 \mathrm{~g}$ 이었으며, $10 \%$ 첨가 된장에서는 각각 106.20 , $129.53,127.46 \mathrm{mg} / 100 \mathrm{~g}$ 으로 함초를 첨가한 된장보다 칠면 초와 나문재 분말을 $5 \%, 10 \%$ 첨가한 된장에서 함량 값이 높게 유지되었다. $\mathrm{Kim}$ 등(20)이 염생식물 자체의 칼슘 함량 이 함초, 칠면초, 나문재 순으로 높다는 보고와 달리 본 연구에서는 염생식물이 첨가된 된장에서의 칼슘 함량은 상이한 결과를 나타내었다.

\section{맛 센서를 이용한 맛 성분 분석}

제조한 된장의 발효 전 후의 맛 변화를 살펴보기 위해 시중 판매되는 된장을 대조군으로 비교 분석하여 대조군의 값을 0으로 하여 그 상대 값을 Fig. 4에 나타내었다.

맛의 풍미를 나타내는 Richness는 대조군으로 사용한 시 판된장에 비해 본 연구에서 제조한 된장에서 모두 높게 나타났으며 염생식물 무첨가군에서는 발효 전 $6.71 \pm 1.27$ (대조군 값 대비) 값에서 발효 후에 $4.73 \pm 0.25$ 로 값이 낮아 졌으나 염생식물을 첨가한 된장에서는 발효 전에 2.34-4.21 의 값을 보였고 발효 후에 4.01-7.52로 더 높아지는 경향을 보였다. 신맛(sourness)은 발효 후에 무첨가군에서 $-0.33 \pm 0.08$ 로 대조군과 비슷한 값을 보였으나 염생식물을 첨가한 된장에서는 -3.65 에서 -1.33 으로 신맛의 강도가 약 했으며 특히 나문재 된장에서는 -1.33 과 -1.58 로 다른 염생 식물에 비해 신맛의 강도가 강한 것으로 보여 이는 산도 결과와 일치하는 것으로 판단된다. 쓴맛(bitterness)에서는 무첨가군은 $-1.44 \pm 0.10$ 이었으며 염생식물 분말 첨가군에 서는 -1.63 에서 -0.27 로 음의 값을 나타내어 대조군에 비해 쓴맛이 약한 것을 알 수 있었다. 또한 감칠맛(umami)는 비슷 하거나 조금 높은 값을 보였다. 맛 센서 기기를 이용한 맛성 분 분석에서는 시판된장에 비해 본 연구의 된장이 맛이 풍부하고 신맛과 쓴맛이 적어 기호도에 긍정적인 영향을 미칠 것으로 보이나 전문 패널요원을 이용하여 보다 정확한 맛 평가를 병행해야할 것으로 사료된다.
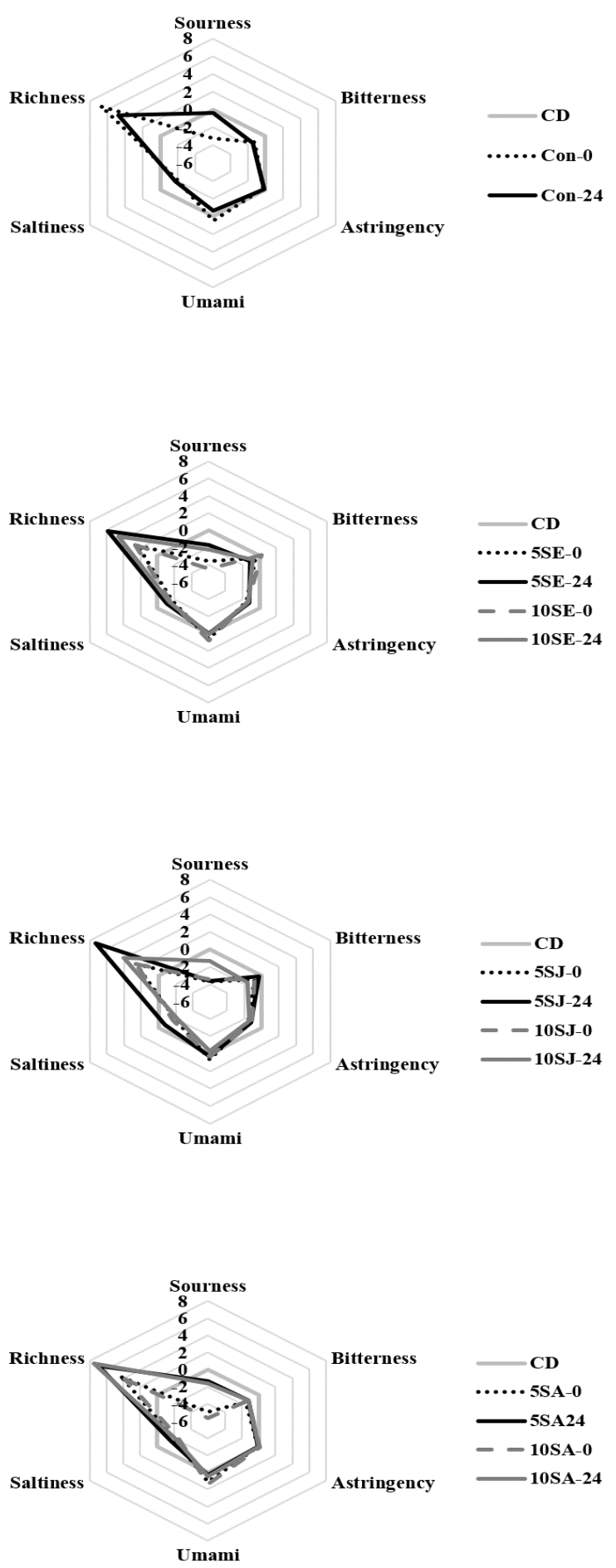

Fig. 4. Taste intensities of the fermented Doenjang by adding halophytes.

CD, commercial Doenjang, Con, Doenjang without halophyte powder; 5SE, Doenjang with 5\% Salicornia europaea, 10SE, Doenjang with $10 \%$ Salicornia europaea; 5SJ, Doenjang with 5\% Suaeda japonica; 10SJ, Doenjang with $10 \%$ Suaeda japonica; 5SA, Doenjang with 5\% Suaeda asparagoides, 10SA, Doenjang with 10\% Suaeda asparagoides, 0 , no fermentation; 24 , fermentation for 24 weeks. 


\section{요 약}

된장의 맛과 품질향상을 위하여 염생식물 분말이 첨가된 된장을 제조하여 24 주 동안 발효하여 이화학적 특성 변화 를 살펴보았다. 된장의 맛 성분을 객관적 수치로 표현한 맛센서의 분석 결과는 richness 값은 대조군으로 사용한 시판된장에 비해 본 연구에서 제조한 된장에서 모두 높게 나타났으며 특히 $5 \%$ 첨가 된장에서 $10 \%$ 첨가 된장보다 높은 값을 나타내었다. 신맛(sourness)과 쓴맛(bitterness)에 서는 제조한 된장이 대조군인 시판된장에 비해 모두 낮은 값을 나타내었고, 감칠맛(umami)은 비슷하거나 조금 높은 값을 보였다. 아미노태 질소 함량은 된장이 발효되면서 증 가하는데, 염생식물 무첨가 된장에 비해서는 첨가군에서 낮은 함량을 보였고, 특히 첨가량 $(5,10 \%)$ 과 반비례적으로 낮은 함량을 나타내었다. 이는 염생식물 함량이 낮을수록 아미노태질소 함량과 richness에서 높은 값을 나타내는 연 관성이 있는 것으로 판단된다. 수분 함량은 발효초기에는 염생식물 분말의 첨가량이 높을수록 된장의 수분 함량은 낮은 경향을 나타내었지만, 발효 후에는 모든 된장에서 $53.5-54.9 \%$ 로 일정한 값을 나타내었다. $\mathrm{pH}$ 값은 발효가 진 행되면서 모든 된장에서 $\mathrm{pH}$ 값이 조금 감소하여 5.3-6.1의 값을 보였고, 산도 변화는 발효가 진행되면서 8 주 차에 최대 값(2.0-2.4\%)을 보였다가 감소하는 경향을 보였다. 된장의 색도는 명도(L), 적색도(a)와 황색도(b) 값이 발효 초기에는 염생식물 분말 첨가량에 따라 차이를 보였으나 발효가 진행 되면서 모든 된장의 값이 비슷한 색을 띠었고, 변색도 $(\Delta \mathrm{E})$ 로 나타내었을 때는 모든 된장은 발효가 진행되면서 점진적 인 변화를 보였고, 특히 염생식물 무첨가 된장에서 색변화 가 크게 나타났다. 된장의 환원당 함량은 발효 2,4 주 차에

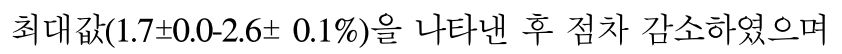
아미노태 질소 함량과는 반대로 염생식물 무첨가군이 가장 낮은 값을 보이고 염생식물 분말의 첨가량이 높아질수록 환원당의 함량도 높아지는 경향을 보였다. 미생물 총 균수 는 발효기간 내 염생식물 분말 첨가 여부와 무관하게 비슷 한 수준을 나타낸 반면, 유산균 수는 담금 초기에는 7.6 $\pm 0.0-8.0 \pm 0.1 \log \mathrm{CFU} / \mathrm{g}$ 으로 검출되었으나 점차 감소되 어 24주 차에는 6.6 $\pm 0.1-6.8 \pm 0.0 \log \mathrm{CFU} / \mathrm{g}$ 로 검출되었다. 결론적으로 저염된장 제조를 위해 첨가한 염생식물 분말에 의해 된장 발효 중 미생물의 생육에는 영향을 미치지 않으 면서, 맛 성분에 있어서 긍정적인 변화를 초래하여 염생식 물 사용으로 기능성과 맛이 향상된 된장을 제조할 수 있을 것으로 판단된다.

\section{감사의 글}

본 연구는 농촌진흥청 농업기초기반 연구개발사업
(PJ012492)의 지원에 의해 이루어진 것입니다.

\section{References}

1. Ku KH, Park KM, Kim HJ, Kim YS, Koo MS (2014) Quality characteristics of Doenjang by aging period. J Korean Soc Food Sci Nutr, 43, 720-728

2. Hwang KM, Oh SH, Park KY (2007) Increased antimutagenic and in vitro anticancer effects by adding green tea extract and bamboo salt during Deonjang fermentation. J Korean Soc Food Sci Nutr, 36, 1-7

3. Oh SI, Sung JM, Lee KJ (2014) Physicochemical charactaristics and antioxidatie effects of barley soybean paste (Doenjang) containing kelp extracts. J Korean Soc Food Sci Nutr, 43, 1843-1851

4. Lee CH, Youn Y, Song GS, Kim YS (2011) Immunostimulatory effects of traditional Doenjang. J Korean Soc Food Sci Nutr, 40, 1227-1234

5. Lee JJ, Kim AR, Lee H, Kim CH, Chang HC, Lee MY (2011) Effects of soybean, Cheonggukjang and Doenjang on serum cholesterol level and weight reduction in rats fed a high-fat/high cholesterol diet. Korean J Food Preserv, 18, 226-235

6. Bae CR, Kwon DY, Cha YS (2013) Anti-obesity effects of salted and unsalted Doenjang supplementation in C57BL/6J mice fed with high fat diet. J Korean Soc Food Sci Nutr, 42, 1036-1042

7. Park JH, Ha, AW, Cho JS (2005) Effects of green tea soybean paste on weights and serum lipid profiles in rats fed high fat diet. Korean J Food Sci Technol, 37, 806-811

8. Cui CB, Lee EY, Lee DS, Ham SS (2002) Antimutagenic and anticancer effects of ethanol extract from Korean traditional Doenjang added sea tangle. J Korean Soc Food Sci Nutr, 31, 322-328

9. Bae JO, Lee KJ, Park JS, Choi DS (2012) Preparation of sweet potato Doenjang using colored sweet potato. Korean J Food Nutr, 25, 529-537

10. Lee SJ, Lee KJ, Rhee SH, Park KY (2004) Physiological activity in Doenjang added with various mushrooms. Korean J Food Cookery Sci, 20, 365-370

11. Choi HS, Kang JE, Jeong ST, Kim CW, Kim MK (2015) Changes obeserved in Doenjang (soybean paste) containing fermented-Rhus verniciflua extract during aging. Korean J Food Sci Technol, 47, 599-607

12. Kang JR, Kim GM, Hwang CR, Cho KM, Hwang CE, Kim JH, Kim JS, Shin JH (2014) Changes in quality 
characteristics of soybean paste Doenjang with addition of garlic during fermentation. Korean J Food Cookery Sci, 30, 435-443

13. Min BM (1998) Vegetation on the west coast of Korea. Ocean polar Res, 20, 167-178

14. Lee HJ, Kim YA, Ahn JW, Lee BJ, Moon SG, Seo $\mathrm{Y}(2004)$ Screening of peroxynitrite and DPPH radical scavenging activities from salt marsh plants. KSBB J, 19, 57-61

15. Kim YA, Um YR, Lee JI, Kim HJ, Lim SY, Nam TJ, Seo YW (2009) Comparative studies on the fatty acid compositions of the Korean salt marsh plants in the west sea. KSBB J, 24, 521-526

16. Kong CS, Kim YA, Kim MM, Park JS, Kim JA, Kim SK, Lee BJ, Nam TJ, Seo Y (2008) Flavonoid glycosides isolated from Salicornia herbacea inhibit matrix metalloproteinase in HT1080 cells. Toxicol In Vitro, 22, $1742-1748$

17. Kong CS (2014) Anti-inflammatory activity of the solvent-partitioned fractions from Spergularia marina in LPS-stimulated RAW 264.7 cells. Prev Nutr Food Sci, 19, 261-267

18. Kong CS, Lee JI, Kwon MS, Seo Y (2015) Inhibitory effect of crude extracts from brown alga Sargassum siliquanstrum on 3T3-L1 adipocyte differentiation. Ocean Polar Res, 37, 279-285

19. Parida AK, Das AB (2005) Salt tolerance and salinity effects on plants. Ecotoxicol Environ Saf, 60, 324-349

20. Kim TG (2010) Hylophytes of South Korea's reclaimed land. National institute of crop science, Rural Development Administration, ISBN 9788948009279

21. Cha JY, Jeong JJ, Kim YT, Seo WS, Yang HJ, Kim JS, Lee YS (2006) Detection of chemical characteristics in Hamcho (Salicornia herbasea L) according to harvest periods. J Life Sci, 16, 683-690

22. Lee KS, Gim JC, Son SM, Lee KY (2011) Antioxidative effect of Suaeda japonica ethanol extract and solvent partitioned fractions. J Korean Soc Food Sci Nutr, 40, 804-808

23. Choi JI, Kim YJ, Kim JH, Kwon JH, Ahn DH, Chun BS, Lee JW (2010) Physiological activities of Suaeda japonica extracts on harvest season. J Korean Soc Food Sci Nutr, 39, 99-104
24. Lee YK, Lee YS, Jung EK (2010) A study of the chemical components of the halophyte Suaeda asparagoides $\mathrm{M}_{\mathrm{IQ}}$. J East Asian Soc Diet Life, 20, 452-457

25. Yoon HJ, Cho EA, Park SY, Kweon MH (2017) Reinforced food quality and functionality of Salicornia europaea by desalination. J Korean Soc Food Sci Nutr, 46, 1468-1476

26. Park KY, Hwang KM, Jung KO, Lee KB (2002) Studies of the standardization of Doenjang (Korean soybean paste): 1. Standardization of manufacturing method of Doenjang by literatures. Korean J Soc Food Sci Nutr, 31, 343-350

27. AOAC (1990) Official methods of analysis, $15^{\text {th }} \mathrm{ed}$, Association of official analytical chemists Washington, DC, USA, p 335

28. KFDA (2015) Korean Food Standards Codex. Korean Food and Drug Administration

29. The Korea Society Food Science and Nutrition (2000)

30. National Agricultural Products Quality Management Service (2012) Traditional Food Quality Certification System. p 88

31. Chang M, Kim IC, Chang HC (2010) Effect of solar salt on the quality characteristics of Doenjang. J Korean Soc Food Sci Nutr, 39, 116-124

32. Kwak EK, Lim SI (2003) Effect of addition time of antibrowning agents on browning and fermentation characteristics in Doenjang. J Korean Soc Food Sci Nutr, 32, 495-500

33. Kim SJ, Moon JS, Park JW, Park IB, Kim JM, Rhim JW, Jung ST, Kang SG (2004) Quality of soybean paste (Doenjang) prepared with sweet tangle, sea mustard and anchovy powder. J Korean Soc Food Sci Nutr, 33, 875-879

34. Byun MW, Nam TG, Chun MS, Lee GH (2014) Physicochemical and sensory characteristics of Doenjang made by traditional methods. J Korean Soc Food Sci Nutr, 43, 1543-1548

35. Lee JO, Ryu CH (2002) Preparation of low salt Doenjang using by nisin-producing lactic acid bacteria. J Korean Soc Food Sci Nutr, 31, 75-80

36. Lee JY, Mok CK (2010) Changes in physicochemical properties of low salt soybean paste (Doenjang) during fermentation. Food Eng Prog, 14, 153-158 